\title{
La normalisation de la terminologie pour l'histoire de l'outillage
}

Johan David

\section{(2) OpenEdition}

1 Journals

Édition électronique

URL : https://journals.openedition.org/tc/861

DOI : $10.4000 /$ tc. 861

ISSN : 1952-420X

Éditeur

Éditions de l'EHESS

\section{Édition imprimée}

Date de publication : 1 septembre 1987

ISSN : 0248-6016

\section{Référence électronique}

Johan David, "La normalisation de la terminologie pour l'histoire de l'outillage », Techniques \& Culture [En ligne], 9 | 1987, mis en ligne le 23 janvier 2006, consulté le 29 septembre 2022. URL : http:// journals.openedition.org/tc/861; DOI : https://doi.org/10.4000/tc.861

\section{Ce document a été généré automatiquement le 29 septembre 2022.}

Tous droits réservés 


\section{La normalisation de la terminologie pour l'histoire de l'outillage}

Johan David 